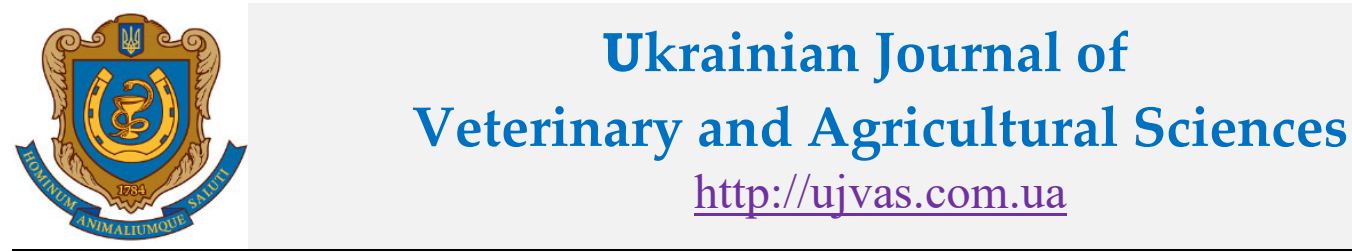

Stepan Gzhytskyi National University of Veterinary Medicine and Biotechnologies Lviv

\begin{tabular}{l|l|l} 
original article & UDC 636.2 .083 .312 .3 & doi: $\mathbf{1 0 . 3 2 7 1 8 / u j v a s 4 - 2 . 0 5}$
\end{tabular}

\title{
Influence of low temperatures on heat balance in easily assembled premises of different types
}

\author{
O. O. Borshch, O. V. Borshch, M. M. Fedorchenko
}

Bila Tserkva National Agrarian University, pl. 8/1 Soborna, Bila Tserkva, 09117, Ukraine

\begin{tabular}{l} 
Article info \\
Received 30.04.2021 \\
Received in revised form \\
31.05.2021 \\
Accepted 01.06.2021 \\
\hline Correspondence author \\
Oleksandr Borshch \\
Tel.: +38-098-622-07-97 \\
E-mail: borshcha@outlook.com \\
\hline
\end{tabular}

2021 Borshch O. et al. This is an open-access article distributed under the terms of the Creative Commons Attribution License, which permits unrestricted use, distribution, and reproduction in any medium, provided the original author and source are credited.

\section{(cc) $\mathrm{BY}$}

\section{Contents}

1. Introduction

3. Results and discussion ........ 28

4. Conclusions .............. 29

References ........................... 29

\begin{abstract}
The purpose of this work was to analyze the thermal balance of easily assembled premises of different types and sizes during the periods of low average daily temperatures. The research was conducted during the winter period of 2020-2021 in the Kyiv region. The used material was easily assembled premises of different types and sizes: easily assembled ones without insulation elements; with elements of warming and premises with deep-litter. In each of the studied premises were kept 400 dairy cows. The studies were performed during two periods: the first period had ambient temperatures from -10 to $-14.9^{\circ} \mathrm{C}$ and the second one from $-15.0^{\circ} \mathrm{C}$ and below. In our studies, the average daily temperature (during the ambient temperature from -10 to $14.9^{\circ} \mathrm{C}$ ) in easily assembled premises with the use of insulation elements was 6.20 and $5.31{ }^{\circ} \mathrm{C}$ higher than in premises without insulation and deeplitter. A similar trend was observed during the period of lowering the ambient temperature up to $15^{\circ} \mathrm{C}$ and below. Thus, the advantage of the premises without insulation constituted $6.28^{\circ} \mathrm{C}$, and of the premises with deep-litter per $5.84{ }^{\circ} \mathrm{C}$, respectively. It was found that keeping in easy-to-assemble premises with insulation elements, the consumption of free thermal energy from the whole herd during the experimental periods was lower compared to the keeping in a boxing cowshed and a cowshed with deep litter. This is due to the smaller range of fluctuations in the average daily temperature in a room with insulation elements. A similar trend was observed for energy consumption through enclosing structures and for moisture evaporation and, accordingly, total heat consumption. In general, heat deficiency was observed during the keeping of cows in the investigated premises of easily assembled type at negative temperatures (-10-14.9 and $-15^{\circ} \mathrm{C}$ and above). Accordingly, the thermal balance of the premises was negative. The highest values of heat balance among easily assembled premises in both research periods were observed for keeping in rooms that used insulation elements.
\end{abstract}

Key words: cows, heat balance, easily assembled premises, low temperatures.

\section{Citation:}

Borshch, O. O., Borshch, O. V., \& Fedorchenko, M. M. (2021). Influence of low temperatures on heat balance in easily assembled premises of different types. Ukrainian Journal of Veterinary and Agricultural Sciences, 4(2), 27-30.

\section{Introduction}

New technological solutions have recently been introduced into animal husbandry in Ukraine, such as livestock premises of the easily assembled type (Ruban et al., 2017; Ruban et al., 2020). The territory of Ukraine is within the temperate climate zone, with four distinct seasons. During the winter period, keeping of animals in this type of premises causes certain problems for both animals and farm staff (Broucek et al., 1991; Hempel et al., 2019; Borshch et al., 2020b). However, the conditions for keeping cows in such premises have not been fully studied: there is no data regarding heat balance, no information about the behavior of animals in the cold season, their productivity and resistance to disease (Cao et al., 2017; Borshch et al., 2019; Angrecka et al., 2020).

The technological process of livestock production is based on three main components: high genetic potential of livestock scientifically grounded feeding and watering of animals, their keeping and care. The most effective output can be obtained only if all the above technological processes work smoothly, rhythmically and without interruption. Any violation of at least one of the components immediately leads to the loss of the planned product (Calamari et al., 2009; Borshch et al., 2021a; Borshch et al., 2021b).

Animal housing conditions are closely intertwined with the state of the microclimate in closed livestock, which is determined by a complex of physical factors (temperature, humidity, air movement, atmospheric pressure, lighting and ionization, industrial noise), gas composition of air (oxygen, carbon dioxide, ammonia, hydrogen sulfide and etc.) and mechanical impurities. The formation of the indoor microclimate depends on the local climate, volumetric planning decisions, the level of air exchange or efficiency of ventilation, heating or cooling, heat-protective properties of enclosing structures, technology of keeping and feeding, manure collection methods, density of animals, etc. (Teye et al., 2008; Rong et al., 2015). 
It is known that keeping cattle in cold, damp, poorly ventilated rooms with drafts leads to reduced productivity, increased feed costs per unit of the product, increased morbidity, reduced natural resistance and immunological reactivity of the organism. The quality of livestock products is declined: milk is contaminated, acquires an ammonia odor, its acidity and bacterial contamination increase (Vaculicova et al., 2017; Borshch et al., 2020a). These and other factors can lead to a significant increase in the cost of keeping animals and obtaining products from them. Creating optimal conditions for animals primarily depends on the indoor air temperature of livestock facilities. The only source of heat in livestock facilities are the cows themselves. The use of additional heating in cowsheds is not always rational. Therefore, it is expedient to achieve reduction of heat losses through enclosing designs. Today, the construction of light livestock facilities becomes popular, so the study of thermal proper- ties of enclosing structures and the development of measures to reduce heat losses is more than relevant.

The purpose of this work was to analyze the thermal balance of easily assembled premises of different types and sizes during the periods of low average daily temperatures.

\section{Materials and methods}

The research was conducted during the winter period of 2020-2021 in the Kyiv region. The used material was easily assembled premises of different types and sizes: easily assembled ones without insulation elements; with elements of warming and premises with deep-litter (figure 1). In each of the studied premises were kept 400 dairy cows. The studies were performed during two periods: the first period had ambient temperatures from -10 to $-14.9{ }^{\circ} \mathrm{C}$ and the second one from $-15.0^{\circ} \mathrm{C}$ and below.

a)

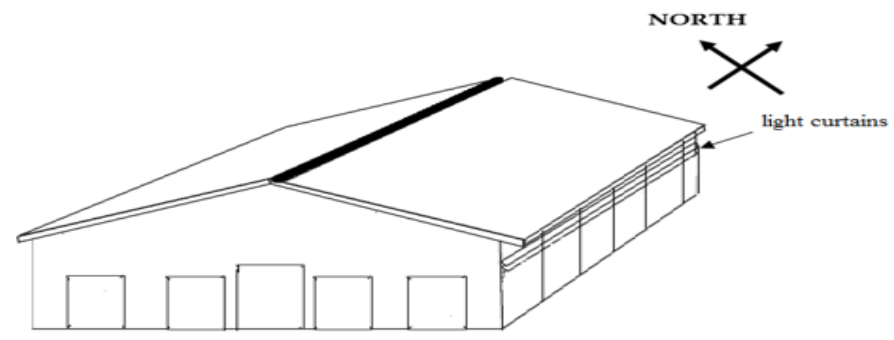

b)

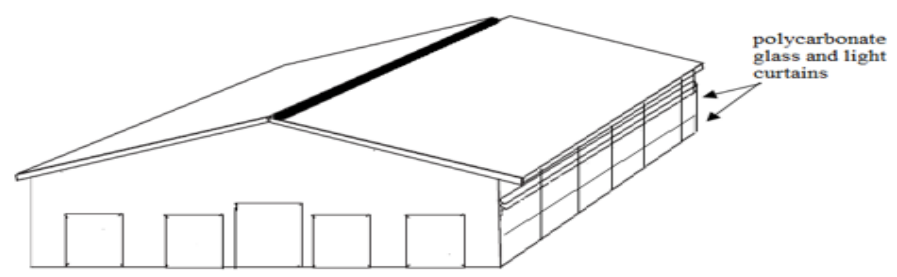

c)

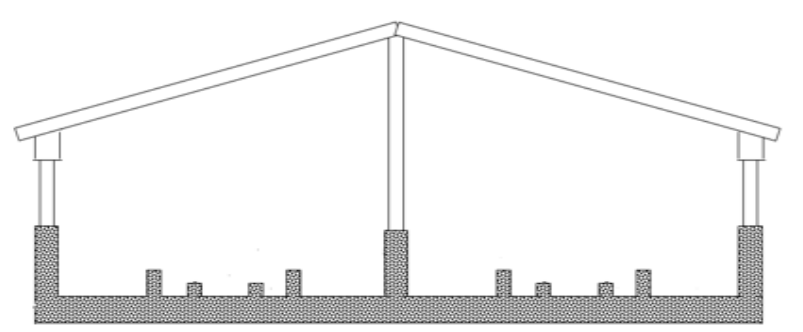

Fig 1. Type of easily assembled premises: a) without insulation elements;

b) with elements of warming; c) premises with deep-litter

The average daily air temperature and relative humidity were determined according to the Kyiv Center for Hydrometeorology.

\section{Results and discussion}

An important element that affects the well-being and comfort of cows is the provision of thermo neutral temperature (from -5 to $+25^{\circ} \mathrm{C}$ ) during all seasons. However, this range is not always possible due to design features and solu- tions. This is especially true for easily assembled premises during the periods of low temperature loads. In our studies, the average daily temperature (during the ambient temperature -10 to $14.9^{\circ} \mathrm{C}$ ) in easily assembled premises with the use of insulation elements was per 6.20 and $5.31{ }^{\circ} \mathrm{C}$ higher than in rooms without insulation and deep litter (Table 1). A similar trend was observed during the period of lowering the ambient temperature to $15{ }^{\circ} \mathrm{C}$ and below. Thus, the advantage of the room without insulation constituted $6.28^{\circ} \mathrm{C}$, and of the room with deep litter per $5.84{ }^{\circ} \mathrm{C}$, respectively. 
Table 1

Temperature in easily assembled rooms of various sizes by 400 heads in winter

\begin{tabular}{|c|c|c|c|c|c|c|}
\hline \multirow{2}{*}{ Indicator } & \multicolumn{6}{|c|}{ Type of easily assembled premises } \\
\hline & \multicolumn{2}{|c|}{ Without heating elements } & \multicolumn{2}{|c|}{ With deep litter } & \multicolumn{2}{|c|}{ With insulation elements } \\
\hline $\begin{array}{l}\text { The average daily } \\
\text { ambient temperature, }{ }^{\circ} \mathrm{C}\end{array}$ & $\begin{array}{l}-10- \\
-14.9\end{array}$ & $\begin{array}{c}-15 \\
\text { and low }\end{array}$ & $\begin{array}{l}-10- \\
-14.9\end{array}$ & $\begin{array}{c}-15 \\
\text { and low }\end{array}$ & $\begin{array}{l}-10- \\
-14.9\end{array}$ & $\begin{array}{c}-15 \\
\text { and low }\end{array}$ \\
\hline $\begin{array}{l}\text { The average daily tem- } \\
\text { perature in the room, }{ }^{\circ} \mathrm{C}\end{array}$ & $-4.17 \pm 0.07$ & $-11.34 \pm 0.12$ & $-3.28 \pm 0.14$ & $-10.90 \pm 0.21$ & $2.03 \pm 0.06$ & $-5.06 \pm 0.09$ \\
\hline $\begin{array}{l}\text { Parameters of premises } \\
(\mathrm{L} \times \mathrm{W} \times \mathrm{H}), \mathrm{m}\end{array}$ & \multicolumn{2}{|c|}{$138 \times 36 \times 9.54$} & \multicolumn{2}{|c|}{$100 \times 60 \times 8$} & \multicolumn{2}{|c|}{$150 \times 36 \times 10.5$} \\
\hline Volume of the room, $\mathrm{m}^{3}$ & \multicolumn{2}{|c|}{47394.72} & \multicolumn{2}{|c|}{48000} & \multicolumn{2}{|c|}{56700} \\
\hline
\end{tabular}

It has been found that that keeping in an easy-toassemble room with insulation elements, the consumption of free thermal energy from the whole herd during the experimental periods was lower compared to the content in a boxing cowshed and a cowshed with deep litter. This is due to the smaller range of fluctuations in the average daily temperature in a room with insulation elements. A similar trend was observed in terms of energy consumption through en- closing structures and the evaporation of moisture and, accordingly, the total heat consumption (Table 2).

The results of our researches partially coincide with the data of Polish researchers, who found that the indicators of heat balance in easily assembled premises during lowtemperature periods were negative (Herbut, 2013; Angrecka \& Herbut, 2015).

Table 2

Heat balance in easily assembled premises of different types and sizes for 400 heads during the periods of low temperatures

\begin{tabular}{|c|c|c|c|c|c|c|}
\hline \multirow{3}{*}{$\begin{array}{l}\text { Indicator } \\
\text { The average daily ambient } \\
\text { temperature, }{ }^{\circ} \mathrm{C}\end{array}$} & \multicolumn{6}{|c|}{ Type of easily assembled premises } \\
\hline & \multicolumn{2}{|c|}{ Without heating elements } & \multicolumn{2}{|c|}{ With deep litter } & \multicolumn{2}{|c|}{ With insulation elements } \\
\hline & $\begin{array}{l}-10- \\
-14.9\end{array}$ & $\begin{array}{c}-15 \\
\text { and low }\end{array}$ & $\begin{array}{l}-10- \\
-14.9\end{array}$ & $\begin{array}{c}-15 \\
\text { and low }\end{array}$ & $\begin{array}{l}-10- \\
-14.9\end{array}$ & $\begin{array}{c}-15 \\
\text { and low }\end{array}$ \\
\hline $\begin{array}{l}\text { Free thermal energy from all } \\
\text { livestock, } \mathrm{kcal} / \mathrm{h}\end{array}$ & 449600 & 449600 & 449600 & 449600 & 449600 & 449600 \\
\hline $\begin{array}{l}\text { Heat consumption for air } \\
\text { heating, } \mathrm{kcal} / \mathrm{h}\end{array}$ & 284731.36 & 387371.21 & 277148.45 & 383525.43 & 269727.64 & 376582.58 \\
\hline $\begin{array}{l}\text { Heat consumption through } \\
\text { enclosing (windows, walls, } \\
\text { ceiling, floor, gate), } \mathrm{kcal} / \mathrm{h}\end{array}$ & 157356.61 & 207772.82 & 152729.20 & 203588.57 & 151572.55 & 200741.76 \\
\hline $\begin{array}{l}\text { Heat consumption for mois- } \\
\text { ture evaporation, } \mathrm{kcal} / \mathrm{h}\end{array}$ & 31487.53 & 44397.41 & 29753.38 & 44056.33 & 29268.74 & 43827.62 \\
\hline $\begin{array}{l}\text { Total heat consumption, } \\
\mathrm{kcal} / \mathrm{h}\end{array}$ & 473575.50 & 639541.44 & 459631.03 & 631170.33 & 450568.93 & 621151.96 \\
\hline Heat balance & -14975.50 & -189941.44 & -10031.03 & -181570.33 & -968.93 & -171551.96 \\
\hline
\end{tabular}

\section{Conclusions}

In general, heat deficiency was observed during the keeping of cows in the investigated premises of easily assembled type at negative temperatures $\left(-10-14.9\right.$ and $-15{ }^{\circ} \mathrm{C}$ and above). Accordingly, the heat balance of the premises was negative. The highest values of heat balance among easily assembled rooms during the both experimental periods were observed for keeping in the premises with insulation elements.

\section{Conflict of interest}

The authors declare that there is no conflict of interest.

\section{References}

Angrecka, S., \& Herbut, P. (2015). Conditions for cold stress development in dairy cattle kept in free stall barn during severe frosts. Czech Journal of Animal Science, 60(2), 81-87. doi: 10.17221/7978-CJAS.

Angrecka, S., Herbut, P., Godyń, D., Vieira, F. M. C., \& Zwolenik, M. (2020). Dynamics of Microclimate Conditions in Freestall Barns During Winter - a Case Study from Poland. Journal of Ecological Engineering, 5, 129-136. doi: 10.12911/22998993/122235.
Borshch, A. A., Ruban, S., Borshch, A. V., \& Babenko, O. I. (2019). Effect of three bedding materials on the microclimate conditions, cows behavior and milk yield. Polish Journal of Natural Science, 34(1), 19-31. URL: http://rep.btsau.edu.ua/ handle/BNAU/2091.

Borshch, O. O., Gutyj, B. V., Borshch, O. V., Sobolev, O. I., Chernyuk, S. V., Rudenko, O. P., Kalyn, B. M., Lytvyn, N. A., Savchuk, L. B., Kit, L. P., Nahirniak, T. B., Kropyvka, S. I., \& Pundyak, T. O. (2020a). Environmental pollution caused by the manure storage. Ukrainian Journal of Ecology, 10(3), 110 114. doi: $10.15421 / 2020142$.

Borshch, O. O., Ruban, S. Yü., Gutyj, B. V., Borshch, O. V., Sobolev, O. I., Kosior, L. T., Fedorchenko, M. M., Kirii, A. A., Pivtorak, Y. I., Salamakha, I. Yu., Hordiichuk, N. M., Hordiichuk, L. M., Kamratska, O. I., \& Denkovich, B. S. (2020b). Comfort and cow behavior during periods of intense precipitation. Ukraine Journal of Ecology, 10(6), 98-102. doi: 10.15421/2020 265.

Borshch, O. O., Ruban, S., \& Borshch, O. V. (2021a). Review: the influence of genotypic and phenotypic factors on the comfort and welfare rates of cows during the period of global climate changes. Agraarteadus, 32(1), 25-34. doi: 10.15159/jas.21.12.

Borshch, O. O., Borshch, O. V., Sobolev, O. I., Nadtochii, V. M., Slusar, M. V., Gutyj, B. V., Polishchuk, S. A., Malina, V. V., Korol, A. P., Korol-Bezpala, L. P., Bezpalyi, I. F., Cherniavskyi, O. O. (2021b). Wind speed in easily assembled premises with dif- 
ferent design constructions for side curtains in winter. Ukrainian Journal of Ecology, 11(1), 325-328. doi: 10.15421/2021_49.

Broucek, J., Letkovicova, M., \& Kovalcuj, K. (1991). Estimation of cold stress effect on dairy cows. International Journal of Biometeorology, 35, 29-32. doi:10.1007/BF01040960.

Calamari, L., Calegari, F., \& Stefanini, L. (2009). Effect of different free stall surfaces on behavioural, productive and metabolic parameters in dairy cows. Applied Animal Behaviour Science, 120, 9-17. doi: 10.1016/j.applanim.2009.05.013.

Cao, Z., Shi, Z., An, X., \& Li, G. (2017). Evaluating the Thermal Insulation of Dairy Barns in Cold Regions via Infrared Thermography. Animal Environment and Welfare - Proceedings of International Symposium 2017, Chongqing, China, 53-60.

Hempel, S., Menz, C., Pinto, S., Galan, E., Janke, D., Estellés, F., Müschner-Siemens, T., Wang, X., Heinicke, J., Zhang, G., Amon, B., del Prado, A., \& Amon, T. (2019). Heat stress risk in European dairy cattle husbandry under different climate change scenarios - uncertainties and potential impacts. Earth System Dynamics, 10, 859-884. doi: 10.5194/esd-10-859-2019.

Herbut, P. (2013). Temperature, humidity and air movement variations inside a free-stall barn during heavy frost. Annals of Animal Science, 13(3), 587-596. doi: 10.2478/aoas-2013-0025.

Rong, L., Liu, D., Pedersen, E.F., \& Zhang, G. (2015). The effect of wind speed and direction and surrounding maize on hybrid ventilation in a dairy cow building in Denmark. Energy and Buildings, 86, 25-34. doi: 10.1016/j.enbuild.2014.10.016.

Ruban, S. Yu., Borshch, O. V., \& Borshch, O. O. (2017). Suchasni tekhnolohiyi vyrobnytstva moloka (osoblyvosti ekspluatatsiyi, tekhnolohichni rishennya, eskizni proekty) [Modern milk production technologies (peculiarities of operation, technological decisions, sketch designs)]. Kharkiv: STYLIZDAT (in Ukrainian).

Ruban, S., Borshch, O. O., Borshch, O. V., Orischuk, O., Balatskiy, Y., Fedorchenko, M., Kachan, A., \& Zlochevskiy, M. (2020). The impact of high temperatures on respiration rate, breathing condition and productivity of dairy cows in different production systems. Animal Science Papers and Reports, 38(1), 61-72. URL: https://www.cabdirect.org/cabdirect/abstract/20203167447.

Teye, F. K., Hautala, M., Pastell, M., Praks, J., Veermäe, I., Poikalainen, V., Pajumägi, A., Kivinen, T., \& Ahokas, J. (2008). Microclimate and ventilation in Estonian and Finnish dairy buildings. Energy and Buildings, 40, 1194-1201. doi: 10.1016/j.enbuild.2007.10.017.

Vaculikova, M., Komzakova, I., \& Chladek, G. (2017). The effect of low air temperature on behaviour and milk production in holstein dairy cows. Acta Universitatis Agricultural Silviculturae Mendelianae Brunensis, 65, 1623-1627. doi: 10.11118/actaun201765051623. 